\title{
Sea cliff at Wissower Bach (Pleistocene stripe 5) - microstructural evidence of large-scale glacitectonism and glacier kinematics
}

\author{
Anna Gehrmann ${ }^{1}$, Heiko Hüneke ${ }^{1}$, Martin Meschede ${ }^{1}$, and Emrys Phillips ${ }^{2}$ \\ ${ }^{1}$ Institut für Geographie und Geologie, Universität Greifswald, Friedrich-Ludwig-Jahn-Str. 17a, 17487 Greifswald, Germany \\ ${ }^{2}$ British Geological Survey, The Lyell Centre, Research Avenue South, Edinburgh, EH14 4AP, UK
}

Correspondence: Anna Gehrmann (anna.gehrmann@uni-greifswald.de)

Relevant dates: $\quad$ Published: 15 August 2019

How to cite: $\quad$ Gehrmann, A., Hüneke, H., Meschede, M., and Phillips, E.: Sea cliff at Wissower Bach (Pleistocene stripe 5) - microstructural evidence of large-scale glacitectonism and glacier kinematics, DEUQUA Spec. Pub., 2, 29-33, https://doi.org/10.5194/deuquasp-2-29-2019, 2019.

Abstract: $\quad$ Soft-sediment thin sections from a SW-dipping thrust fault at the south-western limb of the Wissower Bach syncline (NE Rügen) give rise to the complicated glacitectonic environment in the south-western Baltic Sea region. Micromorphology, microstructural mapping, and macroscale information have led to the development of a detailed model for the evolution of the syncline during late Weichselian glacitectonism.

1 Macrostructural features of the Wissower Bach syncline

The Wissower Bach syncline $\left(54^{\circ} 31.923^{\prime} \mathrm{N}, 13^{\circ} 40.697^{\prime} \mathrm{E}\right)$ is exposed in a ca. $200 \mathrm{~m}$ wide and $40 \mathrm{~m}$ high sea-cliff section $1.5 \mathrm{~km}$ north-east of Sassnitz. The syncline preserves Upper Cretaceous (Maastrichtian) chalk and a comprehensive Pleistocene sedimentary record (Fig. 1). The Pleistocene succession has been subdivided into at least three tills or diamictons (M1 to M3) with intercalated stratified units (I1 and I2) comprising gravel, sand, and clay (abbreviations adapted from Jaekel, 1917).

The NE-verging syncline (axial surface dips to the SW, 200-250/45-50 - dip direction/dip), which is very tight to the isoclinal, is moderately inclined and deforms both the chalk bedrock and unconsolidated pre-M3 Pleistocene glacigenic deposits (Fig. 1). The former lithostratigraphical boundary between the chalk and the Pleistocene record in the southwestern limb has been modified by a SW/WSW-dipping
(260/50) reverse fault. Glacitectonism of the Jasmund Peninsula occurred after accumulation of the I2, i.e. after the Last Glacial Maximum (MIS 2, marine isotope stage), with largescale folding and thrusting occurring in response to a readvance of the Scandinavian Ice Sheet during the Pomeranian W2 phase (around 18.5-16.0 ka) (e.g. Groth, 2003; Müller and Obst, 2006; Kenzler et al., 2015, 2016).

\section{Microstructural features}

Orientated soft-sediment thin sections from two samples (JA03, JA04) (Fig. 1b) were taken from the thrust fault at the south-western limb between Maastrichtian chalk (hanging wall) and Pleistocene deposits (footwall) (Gehrmann et al., 2017; see also van der Meer, 1993; Menzies, 2000). Micromorphology and microstructural mapping were used to understand the complicated glacitectonic environment in the south-western Baltic Sea region (see Phillips et al., 2011, 2013; Vaughan-Hirsch et al., 2013). 


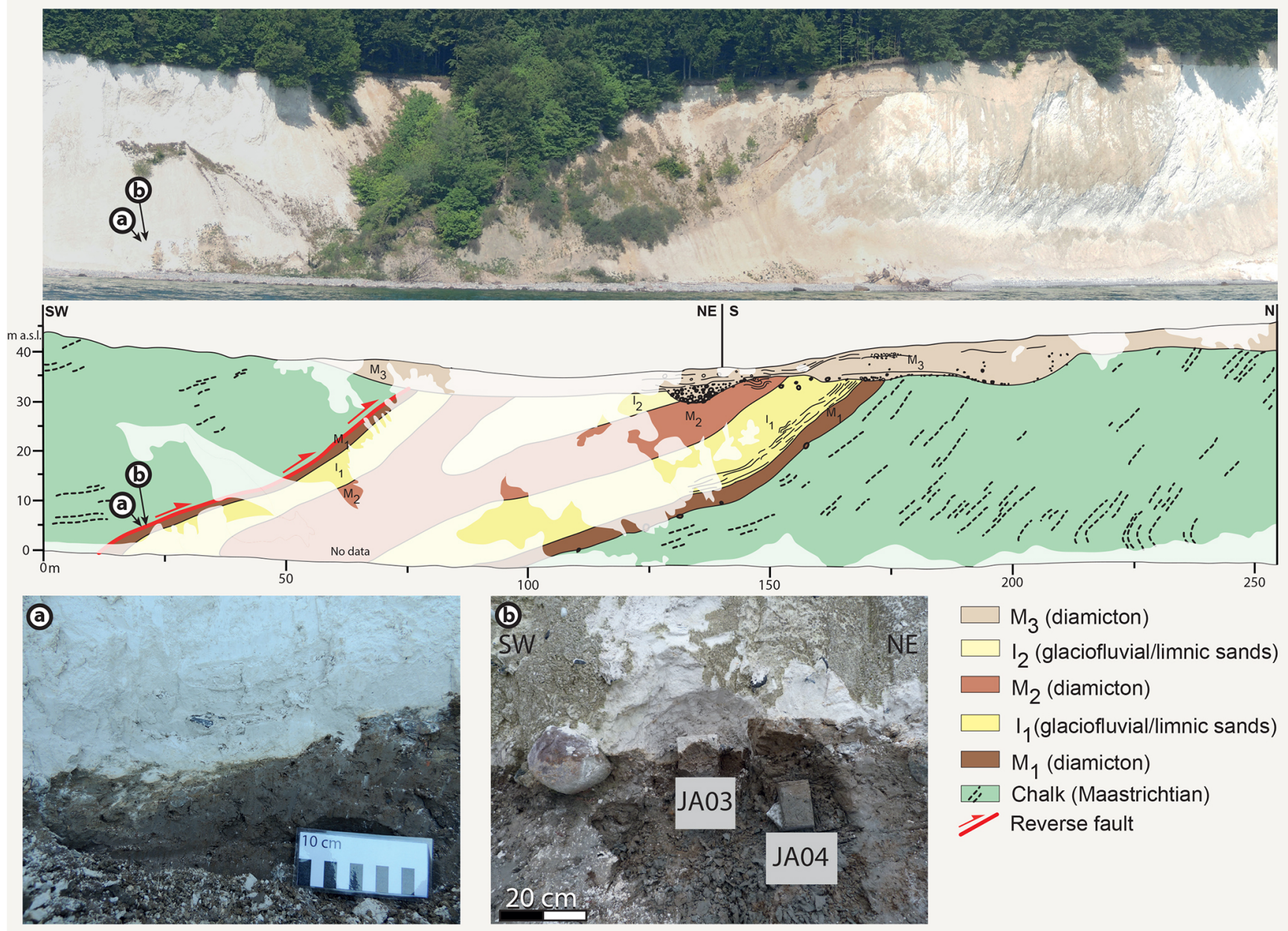

Figure 1. Panoramic image and geological cross section of the Wissower Bach syncline. At the south-western limb of the syncline there is a SW-dipping thrust fault between the Cretaceous chalk and the Pleistocene M1 diamicton below. (a) Tectonic contact between the chalk and the M1 diamicton. (b) Sample blocks JA03 and JA04 at the thrust fault (Gehrmann et al., 2017; abbreviations adapted from Jaekel, 1917).

Within the M1 diamicton which occurs immediately adjacent to the main fault, three different main fabrics were distinguished (Gehrmann et al., 2017). The dominant planar S1 fabric (oldest) dips approximately towards the north and is divided into the two sub-fabrics S1a (gently inclined) and S1b (steep) (Fig. 2). S2 is a linear fabric, dips to the south (perpendicular to S1), and can be divided into steeper (S2a) and more gently inclined (S2b) components. The youngest fabric, S3, is a planar-to-anastomosing subvertical foliation, which is interpreted as having formed in response to the dewatering of the till.

3-D analysis of the clast microfabrics has revealed that S1 shows a change of orientation with increasing proximity to the fault indicative of an anti-clockwise rotation of $\sim 70$ to $90^{\circ}$ (Fig. 2). Adjacent to the chalk-diamicton boundary (JA03), S1 dips at a moderate angle towards the NW (S1a 307/48, S1b - 307/55). In sample JA04, in contrast, S1 dips to the NE (S1a - 042/20, S1b - 042/54). The S2 domains are orientated perpendicular to S1. As with S1, the S2 fabric shows a pronounced change in orientation (anti-clockwise rotation) with decreasing distance to the chalk-diamicton boundary. In sample JA03, adjacent to the chalk-diamicton boundary, S2 is moderately inclined to the SE (S2a - 136/49, $\mathrm{S} 2 \mathrm{~b}-136 / 31)$, whereas in sample JA04, S2 plunges towards the SW (S2a - 214/44, S2b-214/68). In contrast to both S1 and $\mathrm{S} 2$, the $\mathrm{S} 3$ fabric shows a relatively consistent orientation in both samples indicating that the imposition of this foliation post-dated the deformation responsible for the rotation of the earlier-formed S1 and S2 fabrics.

\section{The link between the microstructural architecture and large-scale glacitectonism}

The combination of 3-D microstructural analysis and macroscale information of the Wissower Bach syncline gives rise to a detailed four-stage model of imbricate-fan forma- 


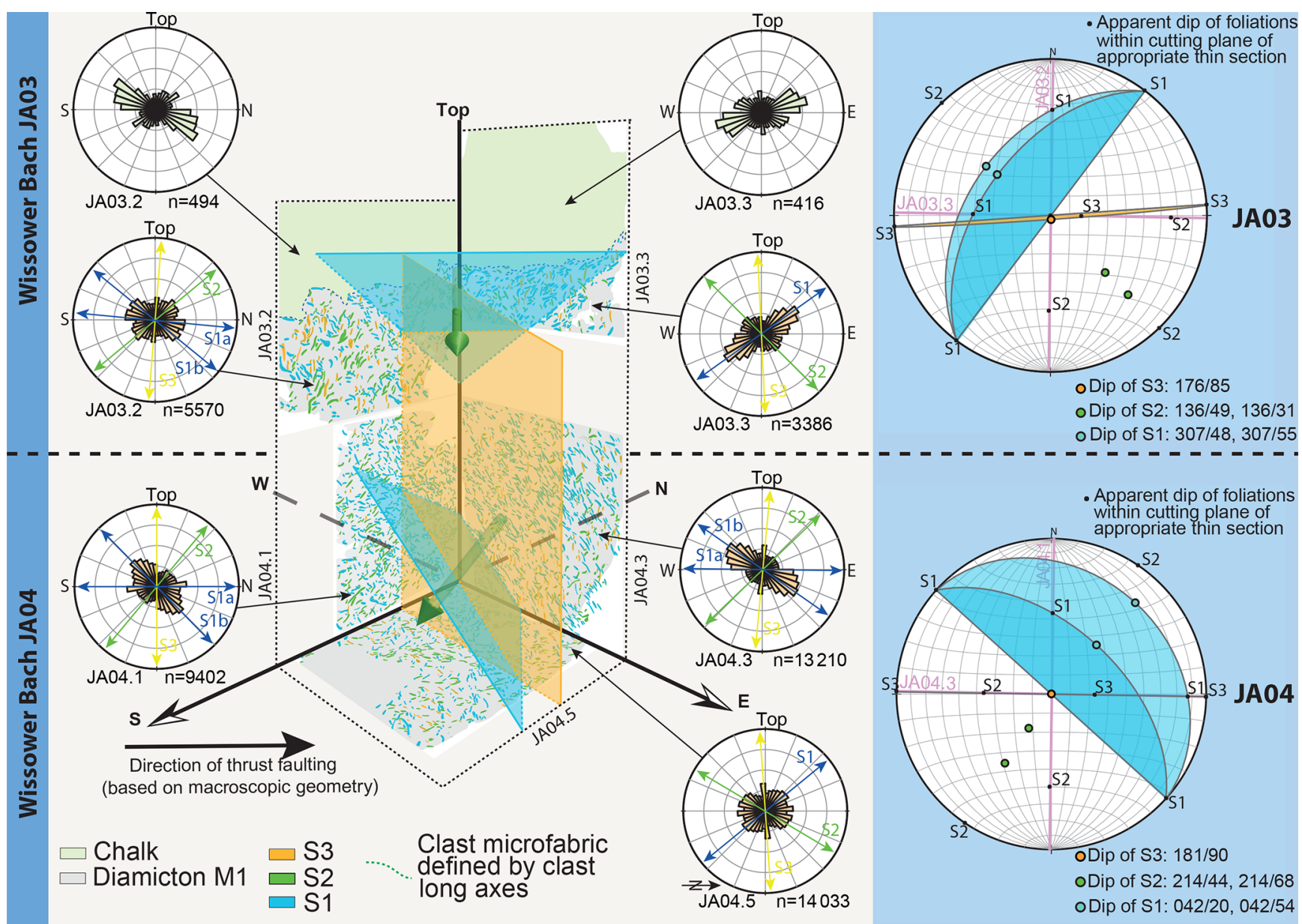

Figure 2. The 3-D model of the microfabric system at the faulted chalk-diamicton contact (samples JA03, JA04). The lower-hemisphere stereographic plots show the orientation of microfabrics S1-S3, their shape (linear/planar) and their spatial relationship to each other (Gehrmann et al., 2017).

tion by ice-push from the south (Fig. 3) (Gehrmann et al., 2017). The evolution starts with an overall sense of compressional movement to the NE leading to the formation of the Wissower Bach syncline (first stage). This was accompanied by flexural slip along the lithological boundary between the chalk and the diamicton, and the imposition of the $\mathrm{S} 1$ and $\mathrm{S} 2$ microfabrics within the M1 diamicton. The clast fabric developed as Riedel shears with the planar S1 fabric representing $\mathrm{R}$ shears (narrow zones of extension, kinematically corresponding to normal faults) and the linear fabric $\mathrm{S} 2$ indicating $\mathrm{P}$ shears that correspond to reverse faults, thus zones of compression (see Fossen, 2010).

Continued compression led to progressive folding and further tightening of the Wissower Bach syncline (second stage). This may have accompanied the overturning and localised thrusting on the southern limb of the syncline. During this deformation, the earlier-formed S1 microfabric was crenulated with axial surfaces of these microfolds occurring coplanar to the adjacent S2 fabric.
This folding was followed by the anti-clockwise rotation of the microfabrics in a narrow shear zone developed along the tectonic contact between the M1 diamicton and chalk; probably as the ice partly overrode the Jasmund Peninsula (third stage). This rotation of the microfabrics clearly records a change in the orientation in stress regime, possibly in response to changes in the local ice-movement direction as the glacier progressively overrode the peninsula. On a larger scale, during this stage of the ice sheet advance the top of the glacitectonised sequence was eroded, accompanied by the deposition of the M3 subglacial traction till (see Brumme et al., 2019).

The evolution ended in dewatering of the sediments and a late-stage reactivation (normal faulting due to gravitational relaxation) at the south-western limb of the Wissower Bach syncline as the ice retreated (fourth stage). The S3 domains represent anastomosing conduits or fluid pathways taken by the escaping porewater. This can be confirmed by the character of the contact between the chalk and the diamicton at both the macro- and microscale, which shows a ductile structure 


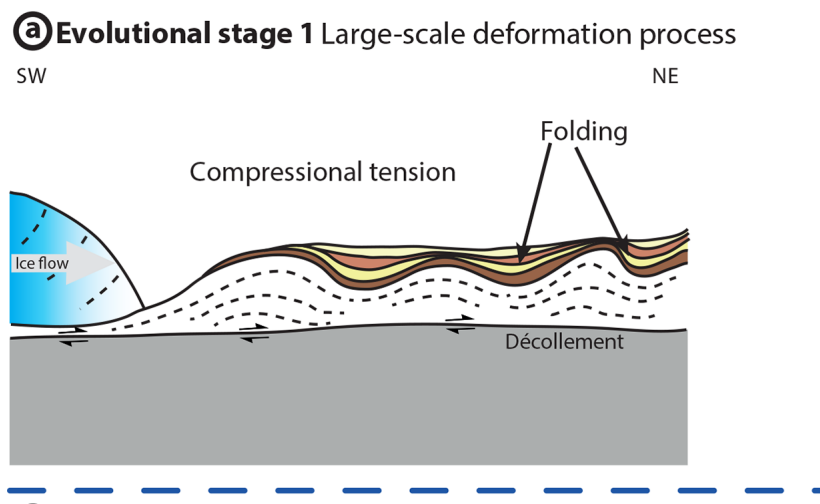

Micro-scale deformation process
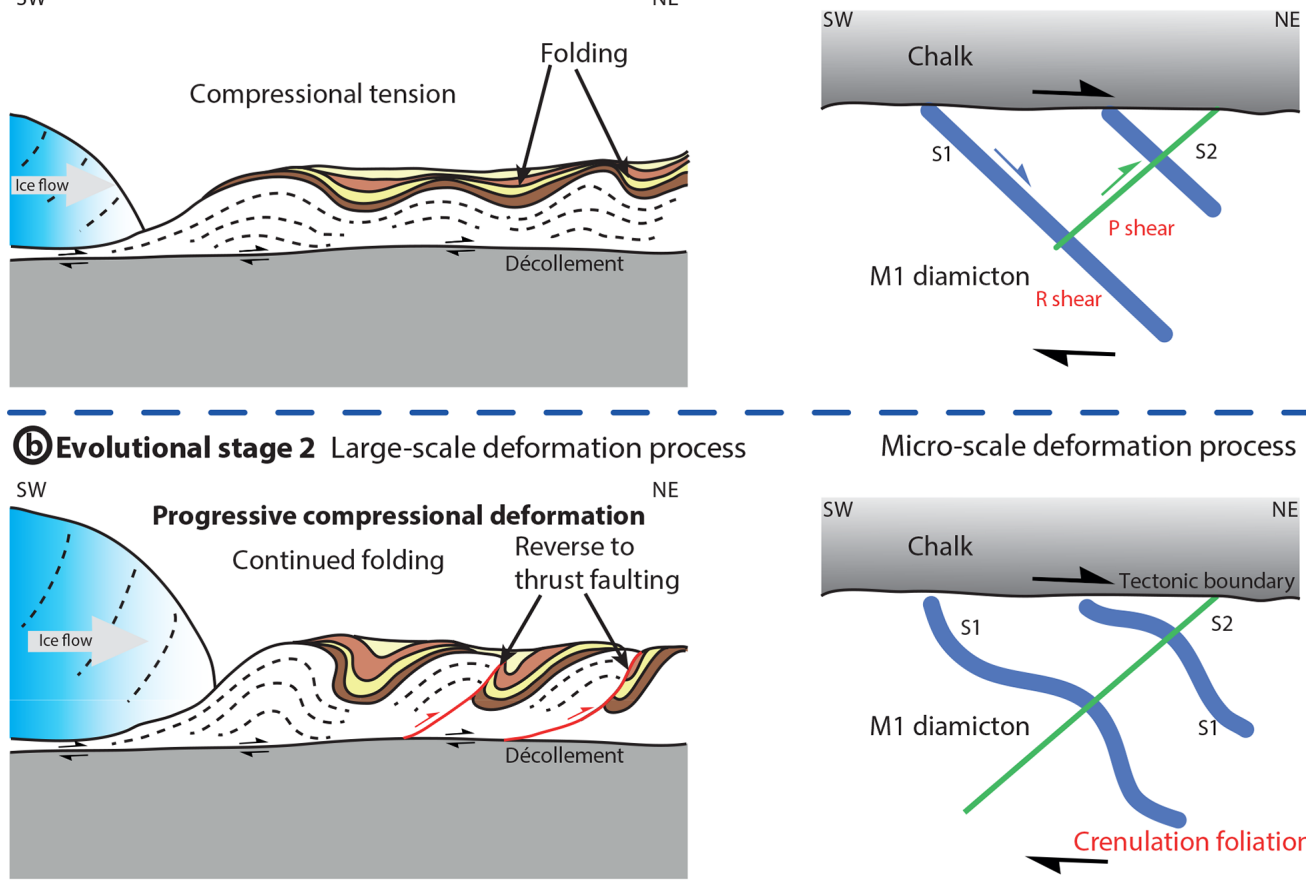

M1 diamicton Rshear

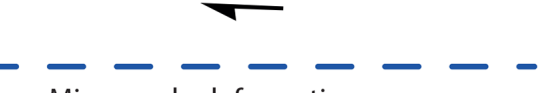

Micro-scale deformation process

(C) Evolutional stage 3 Large-scale deformation process SW Change of the stress orientation NE from a source in the SW to one in the SE

Manipulation of the microfabric
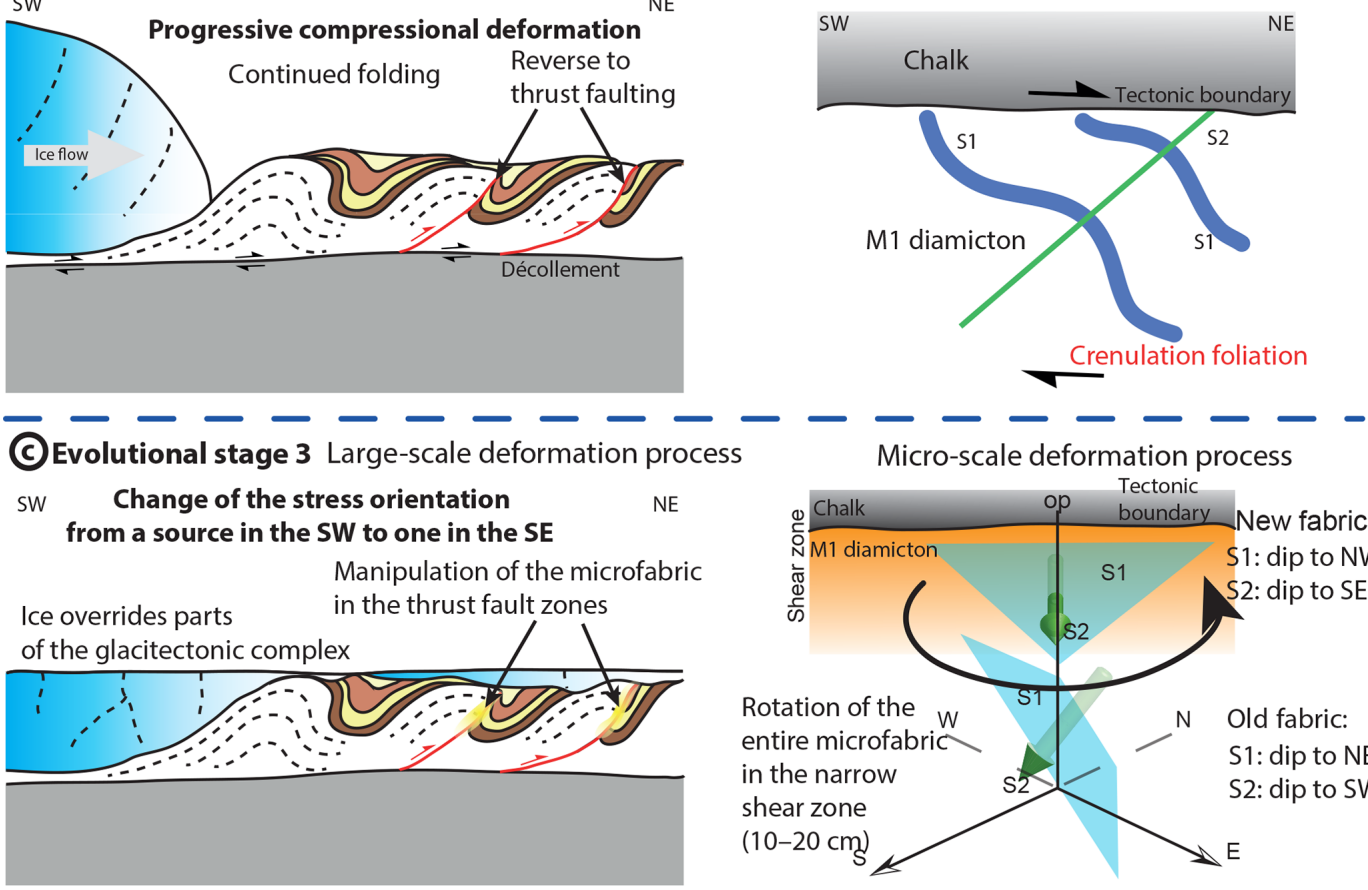

Micro-scale deformation process

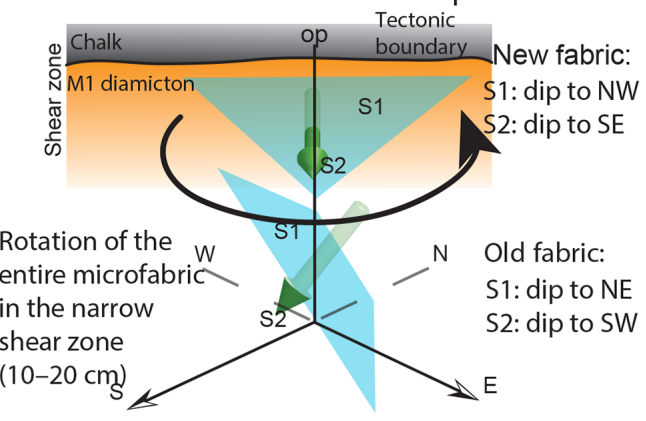

(d)Evolutional stage 4 Large-scale deformation process
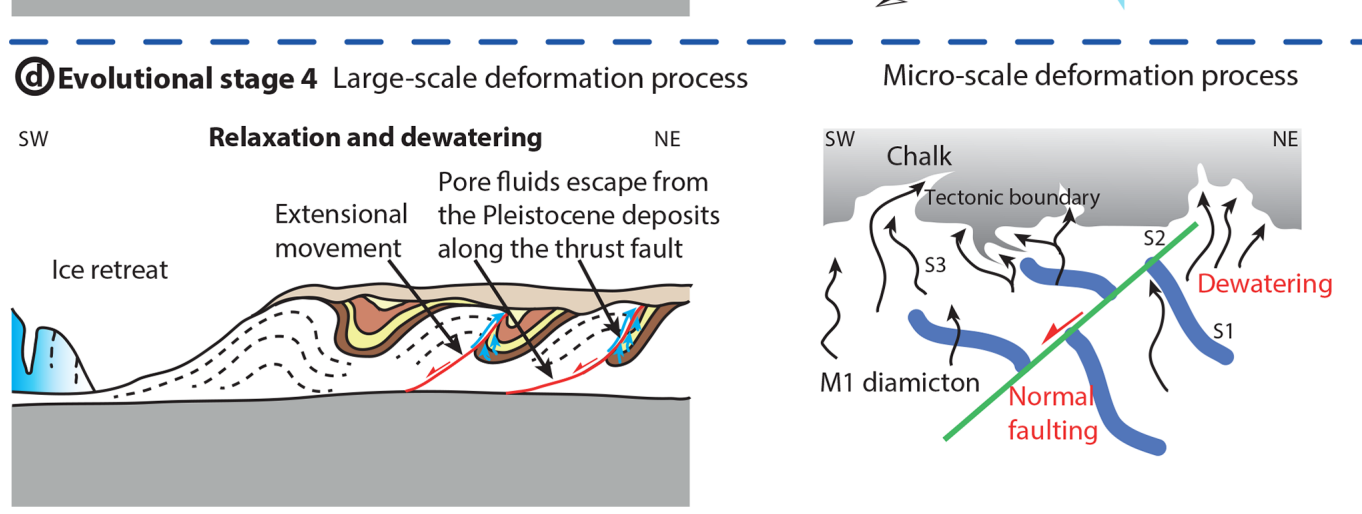

Figure 3. Four-stage evolutional model of the Wissower Bach syncline and adjacent structures including the microstructural development. (a) Stage 1: imposition of large-scale folds leading to the formation of the microfabrics S1 (dip to NE) and S2 (dip to SW) as part of a Riedel shear zone. (b) Stage 2: continuation of folding and thrusting leading to progressive deformation of S1 (crenulation) and S2 at microscale. (c) Stage 3: anti-clockwise rotation of S1 and S2 within the narrow shear zone $(10-20 \mathrm{~cm})$ of the thrust fault presumably by the partial overburden of the glacitectonic complex due to the proceeding ice. (d) Stage 4: retreat of the ice and associated relaxation ending in local microscale normal-fault movements along the S2 microfabric and dewatering of the M1 diamicton, which produces a ductile deformation of the tectonic boundary and formation of the S3 microfabric (Gehrmann et al., 2017). 
and interfingering of both depositional units by porewater escape. Also during the fourth stage, the $\mathrm{S} 2$ foliation has been reactivated. Locally, it displays normal faults which crosscut and dislocate the earlier-developed S1 domains. This microstructural relationship records a generally south-directed extension during a late phase of the proposed polyphase deformation history recorded by the M1 diamicton.

Data availability. The dataset can be found in the database of the Institute for Geography and Geology of the University of Greifswald (Chair of Regional and Structural Geology) and in Gehrmann et al. (2017).

Author contributions. AG, HH, and EP designed the methodology and performed the analysis. AG prepared the article with contributions from all co-authors.

Competing interests. The authors declare that they have no conflict of interest.

Acknowledgements. The Nationalparkamt Vorpommern is thanked for granting the approval to work in the Jasmund National Park. We thank Sylvia Weinert (University of Greifswald) for careful preparation of the thin sections. The constructive comments of an unknown reviewer substantially improved our article. We acknowledge support for the article processing charge from the DFG (no. 393148499) and the Open Access Publication Fund of the University of Greifswald.

Financial support. This research has been supported by the DFG (German Research Foundation, grant no. 393148499) and the Open Access Publication Fund of the University of Greifswald.

\section{References}

Brumme, J., Hüneke, H., and Phillips, E. R.: Micromorphology and clast microfabrics of subglacial traction tills at the sea-cliff Dwasieden: evidence of polyphase syn- and post-depositional deformation, DEUQUA Spec. Pub., this volume, 2019.

Fossen, H. (Ed.): Structural Geology, Campridge University Press, New York, 2010.
Gehrmann, A., Hüneke, H., Meschede, M., and Phillips, E. R.: 3D microstructural architecture of deformed glacigenic sediments associated with large-scale glacitectonism, Jasmund Peninsula (NE Rügen), Germany, J. Quaternary Sci., 32, 213 230, https://doi.org/10.1002/jqs.2843, 2017.

Groth, K.: Zur glazitektonischen Entwicklung der Stauchmoräne Jasmund/Rügen, Schriftenreihe des Landesamtes für Umwelt, Naturschutz und Geologie Mecklenburg-Vorpommern, 3, 39-49, 2003.

Jaekel, O.: Neue Beiträge zur Tektonik des Rügener Steilufers, Zeitschrift der Deutschen Geologischen Gesellschaft, 69, 81176, 1917.

Kenzler, M , Tsukamoto, S., Meng, S., Thiel, C., Frechen, M., and Hüneke, H.: Luminescence dating of Weichselian interstadial sediments from the German Baltic Sea coast, Quat. Geochronol., 30, 251-256, https://doi.org/10.1016/j.quageo.2015.05.015, 2015.

Kenzler, M., Tsukamoto, S., Meng, S., Frechen, M., and Hüneke, H.: New age constraints from the SW Baltic Sea area - implications for Scandinavian Ice Sheet dynamics and palaeoenvironmental conditions during MIS 3 and early MIS 2, Boreas, 46, 34-52, https://doi.org/10.1111/bor.12206, 2016.

Menzies, J.: Micromorphological analyses of microfabrics and microstructures indicative of deformation processes in glacial sediments, Geol. Soc. London Spec. Pub., 176, 245-257, https://doi.org/10.1144/GSL.SP.2000.176.01.19, 2000.

Müller, U. and Obst, K: Lithostratigraphie und Lagerungsverhältnisse der pleistozänen Schichten im Gebiet von Lohme (Jasmund/Rügen), Zeitschrift für geologische Wissenschaften, 34, 39-54, 2006.

Phillips, E. R., van der Meer, J. J. M., and Ferguson, A.: A new "microstructural mapping" methodology for the identification, analysis and interpretation of polyphaser deformation within subglacial sediments, Quaternary Sci. Rev., 30, 25702596, https://doi.org/10.1016/j.quascirev.2011.04.024, 2011.

Phillips, E. R., Lipka, E., and van der Meer, J. J. M.: Micromorphological evidence of liquefaction, injection and sediment deposition during basal sliding of glaciers, Quaternary Sci. Rev., 81, 114-137, https://doi.org/10.1016/j.quascirev.2013.10.005, 2013.

van der Meer, J. J. M.: Microscopic evidence of subglacial deformation, Quaternary Sci. Rev., 12, 553-587, https://doi.org/10.1016/0277-3791(93)90069-X, 1993.

Vaughan-Hirsch, D. P., Phillips, E. R., and Lee, J. R.: Micromorphological analysis of poly-phase deformation associated with the transport and emplacement of glaciotectonic rafts at West Runton, north Norfolk, UK, Boreas, 42, 376-394, https://doi.org/10.1111/j.1502-3885.2012.00268.x, 2013. 